\title{
Sistem Pakar Untuk Mendiagnosa Kerusakan Mesin Fotocopy Canon IR 6000 Menggunakan Metode Certainty Factor
}

\author{
Juandi Syahputra Simatupang ${ }^{1}$, Erwin Panggabean, ST.,M.Kom ${ }^{2}$
}

1,2STMIK Pelita Nusantara, Teknik Informatika, Indonesia

juandisyahfutra@gmail.com ${ }^{1}$, erwinpanggabean8@gmail.com²

\begin{abstract}
Abstrak
Mesin fotocopy merupakan mesin yang dirancang untuk memperbanyak dokumen hitam putih menjadii beberapa rangkap. Ketika proses pengcopyan berlangsung sering terjadi kerusakan yang bermacam-macam yang sebagian besar hanya dapat diperbaiki oleh teknisi. Kedatangan Teknisi untuk memperbaiki memerlukan waktu berjam-jam. Maka dibutuhkan sebuah sistem pakar yang dapat dengan cepat untuk mengetahui jenis kerusakan mesin fotocopy dan cara penanganannya.Sistem pakar adalah sebuah sistem yang menggunakan pengetahuan manusia di mana pengetahuan tersebut dimasukkan kedalam sebuah komputer dan kemudian digunakan untuk menyelesaikan masalah-masalah yang biasanya membutuhkan kepakaran atau keahlian manusia.Salah satu penerapan sistem pakar untuk mendiagnosa kerusakan mesin fotocopy adalah dengan menggunakan metode certainty factor. Metode certainty factor merupakan suatu metode yang digunakan untuk memecahkan permasalahan dari jawaban yang tidak pasti, dan menghasilkan jawaban yang tidak pastii pula. Ketidakpastian ini dipengaruhi oleh dua faktor yaitu aturan yang tidak pasti dan jawaban pengguna yang tidak pasti. Penelitian bertujuan untuk membangun aplikasi sistem pakar untuk penanganan masalah kerusakan mesin fotocopy Canon IR 6000 menggunakan aplikasi Visual Basic 2010 sebagai alat bantu untuk Merancang aplikasi dan menggunakan Database MySQL sebagai database. Sistem pakar ini mampu melakukan perhitungan similarity dalam perhitungan bobot berdasarkan gejala kerusakan mesin fotocopy menggunakan metode certainty factor dan menampilkan laporan dengan menggunakan crystal report.
\end{abstract}

Keywords - Fotocopy, Expert System, Certainty Factor

\section{LATAR BELAKANG}

Dokumen merupakan salah satu sarana yang sangat penting bagi kehidupan manusia diera modern ini. Sarana dokumen masih sangat vital untuk berlangsungnya kehidupan. Dari dunia sekolah, kampus, dan perkantoran pun masih menggunakan dokumen sebagai kebutuhan mereka sehari-hari. Pentingnya dokumen untuk menjadi sarana belajar, bekerja dan kegiatan lainnya tidak lepas dari peran mesin printer dan komputer sebagai sarana pembuat dan pencetak dokumen. Tetapi seiring dengan kebutuhan dokumen yang tidak hanya untuk para guru, dosen, ataupun pimpinan perusahaan saja, melainkan untuk para pelajar, mahasiswa, dan karyawan-karyawan yang jumlahnya sangat banyak.

Kebutuhan untuk memperbanyak dokumen itu sangatlah penting. Oleh karena itu peran yang sangat vital untuk masalah ini adalah mesin fotocopy. Dengan mesin fotocopy, efisiensi biaya pencetakan bisa lebih sedikit di tekan, waktu pun terasa lebih dimaksimalkan dan tentunya mempermudah urusan orang banyak. Seiring dengan meningkatnya kebutuhan manusia untuk memperbanyak dokumen setiap harinya, maka banyak pengusaha yang memilih medirikan usaha yang bergerak dibidang fotocopy.

Fotocopy Canon IR 6000 merupakan jenis mesin fotocopy canon terbaru yang harganya terjangkau namun dapat memberikan hasil yang sangat maksimal, dengan kecepatan hingga 60 lembar permenit. Selain itu, fotocopy Canon IR 6000 sangat handal karena memang sengaja dirancang untuk penggunaan copy berskala besar. Namun pada saat proses pengcopyan dokumen berlangsung, sering sekali terjadi masalah, seperti kerusakan pada mesin fotocopy yang mengakibatkan hasil dari pengcopyan yang kurang maksimal dan waktu pengerjaan yang menjadi lebih 
lambat. Kerusakan yang muncul tidaklah satu macam saja, namun bermacam - macam. Sehingga ketika kerusakan mesin Fotocopy tersebut muncul, operator fotocopy menjadi bingung karna tidak bisa mengatasi masalah tersebut dengan keahliannya sendiri.

Memang masalah tersebut bisa saja cepat teratasi dengan memanggil tenaga ahli ataupun teknisi. Namun proses pemanggilan teknisi sering sekali memerlukan waktu yang lama karna jarak yang cukup jauh, maupun jam terbangnnya yang padat, yang menimbulkan proses pengcopyan menjadi tertunda Sehingga masalah seperti ini harus segera diatasi dengan merancang sebuah sistem yang dapat membantu mendiagnosa dan memberikan solusi perbaikan kerusakan Fotocopy tanpa bantuan secara langsung dari tenaga ahli ataupun teknisi, atau lebih dikenal dengan sistem pakar.

Sistem pakar adalah sistem berbasis komputer yang menggunakan pengetahuan, fakta, dan teknik penalaran dalam memecahkan masalah yang biasanya hanya dapat dipecahkan oleh seorang pakar dalam bidang tertentu [1].

Penelitian ini menggunakan metode certainty factor dengan metode tersebut pengguna dapat mengetahui tingkat kepastian kerusakannya. Penerapan metode certainty factor sangat baik digunakan pada sistem pakar diagnosa kerusakan mesin sehingga dapat diketahui hasil tingkat kepastian diagnosa kerusakan mesin[2].

\section{Metode}

Teori certainty factor (CF) diusulkan oleh Shortlife dan Buchanan pada 1975 untuk mengakomodasi ketidakpastian pemikiran (inexact reasoning) seorang pakar. Seorang pakar, (misalnya dokter) sering kali menganalisis informasi yang ada dengan ungkapan seperti "mungkin", "kemungkinan besar", "hampir pasti". Untuk mengakomodasi hal ini kita menggunakan certainty factor (CF) guna menggambarkan tingkat keyakinan pakar terhadap masalah yang sedang dihadapi $* 10+$.

Certainty Factor didefenisikan sebagai berikut :

$\mathrm{CF}(\mathrm{H} . \mathrm{E})=\mathrm{MB}(\mathrm{H} . \mathrm{E})-\mathrm{MD}(\mathrm{H} . \mathrm{E})$

Dimana :

$\mathrm{CF}(\mathrm{H}, \mathrm{E})$ : Certainty factor dari hipotesis $\mathrm{H}$ yang dipengaruhi oleh gejala (evidence) E. Besarnya CF Berkisar antara -1 sampai dengan .nilai -1 maenunjukkan nilai ketidakpercayaan mutlak sedangkan nilai 1 menunjukkan kepeecayaan mutlak.

$\mathrm{MB}(\mathrm{H}, \mathrm{E})$ : ukuran kenaikan kepercayaaan (measurevof increased belief) terhadap hipotesis $H$ yang dipengaruhi oleh gejala $\mathrm{E}$.

$\mathrm{MD}(\mathrm{H}, \mathrm{E})$ : ukuran kenaikan ketidakpercayaan (measure of increased disbelief) terhadap hipotesis $\mathrm{H}$ yang dipengaruhi gejala $\mathrm{E}$
Faktor kepastian (CF) menunjukkan jaringan kepercayaan dalam suatu hipotesis yang berdasarkan pada beberapa fakta atau gejala dalam bidang kedokteran *7+. CF positif bermakna fakta mendukung hipotesis karena $\mathrm{MB}>\mathrm{MD}$. CF = 1 mengandung arti bahwa fakta secara defenisi membuktikan suatu hipotesis. $\mathrm{CF}=0$ berarti salah satu dari dua kemungkinan, yaitu pertama $C F=M B-M D=0$ keduanya MB dan MD adalah nol yang berarti tidak ada fakta. Kemungkinan kedua adalah bahwa $\mathrm{Md}=\mathrm{MB}$ dan keduanya tidak sama dengan nol yang berarti bahwa kepercayaan dihapus atau ditiadakan oleh ketidakpercayaan $* 4+$.

Ada dua cara dalam mendapatkan tingkat keyakinan (CF) dari sebuah rule $* 4+$ yaitu:

a. Metode Net Belief' yang diusulkan oleh E.H. Shortliffe dan B.G. Buchanan.

$\mathrm{CF}($ Rule $)=\mathrm{MB}(\mathrm{H}, \mathrm{E})$.......

$M B(H, E)=\left\{\begin{array}{cc}1 & P(H)=1 \\ \frac{\max ^{*} P(H \mid E), P(H)+-P(H)}{M a x^{*} 1,0+-P(H)} \text { lainnya. }\end{array}\right.$

$M D(H, E)=\left\{\begin{array}{cl}1 & P(H)=0 \\ \frac{\min * P(H \mid E), P(H)+-P(H)}{M i n * 1,0+-P(H)} & \text { lainnya ............. }\end{array}\right.$

Dimana:

$\mathrm{CF}$ (Rule) = faktor kepastian

$\mathrm{MB}(\mathrm{H}, \mathrm{E})=$ measure of belief (ukuran kepercayaan) terhadap hipotesis $\mathrm{H}$, jika diberikan evidence $\mathrm{E}$ (antara 0 dan 1 ).

$\mathrm{MD}(\mathrm{H}, \mathrm{E})=$ measure of disbelief (ukuran ketidakpercayaan) terhadap evidence $\mathrm{H}$, jika diberikan evidence $\mathrm{E}$ (antara 0 dan 1).

$\mathrm{P}(\mathrm{H}) \quad$ = probabilitas kebenara hipotesis $\mathrm{H}$.

$\mathrm{P}(\mathrm{H} \mid \mathrm{E}) \quad=\quad$ probalitas bahwa $\mathrm{H}$ benar karena fakta $\mathrm{E}$.

b. Dengan cara mewawancarai seorang pakar

Nilai CF(rule) didapat dari interpretasi "term" dari pakar, yang diubah menjadi nilai CF tertentu sesuai tabel berikut:

TABEL 1

FAKTOR KEYAKINAN PAKAR

\begin{tabular}{|c|c|}
\hline Certainty Term & $\mathrm{CF}_{\text {Akhir }}$ \\
\hline Definitely not (pasti tidak) & -1.0 \\
\hline Almost certainly not (hampir pasti tidak) & -0.8 \\
\hline Probably not (kemungkinan besar tidak) & -0.6 \\
\hline Maybe not (mungkin tidak) & -0.4 \\
\hline Unknown (tidak tahu) & $-0.2-0.2$ \\
\hline Maybe (mungkin) & 0.4 \\
\hline Probably (kemungkinan besar) & 0.6 \\
\hline Almost certainly (hampir pasti) & 0.8 \\
\hline Definitely (pasti) & 1 \\
\hline
\end{tabular}

Formula dasar digunakan apabila belum ada nilai CF untuk setiap gejala yang menyebabkan penyakit. Kombinasi certainty factor yang digunakan untuk mengdiagnosa penyakit adalah : 
1. Certainty Factor untuk kaidah dengan premis/gejala tunggal (single premis rules):

$\mathrm{CF}_{\text {gejala }}=\mathrm{CF}_{\text {user }} *{ } \mathrm{CF}_{\text {pakar }}+$

2. Apabila terdapat kaidah dengan kesimpulan yang serupa (similiary concluded rules) atau lebih dari satu gejala, maka CF selanjutnya dihitung dengan persamaan:

$\mathrm{CF}_{\text {combine }}=\mathrm{CF}_{\text {old }}+\mathrm{CF}_{\text {gejala }} *\left(\mathbf{1}-\mathrm{CF}_{\text {old }}\right)$

3. Sedangkan untuk menghitung persentase terhadap penyakit, digunakan persamaan: $\mathrm{CF}=\mathrm{CF}$ combine

Untuk menentukan keterangan faktor keyakinan dari pakar, dilihat dari CFcombine dengan berpedoman dari tabel faktor keyakinan pakar pada tabel 2. Pada sesi diagnosa penyakit, diberikan pilihan interpretasi yang masing-masing memiliki nilai CF sebagai berikut:

- Tidak Yakin

$$
\begin{aligned}
& =0.0 \\
& =0.1-0.3 \\
& =0.4-0.5 \\
& =0.6-0.7 \\
& =0.8-0.9 \\
& =1.0
\end{aligned}
$$$$
\text { Ya) Kurang Yakin }
$$

(Ya) Yakin

- (Ya) Sangat Yakin

Proses penghitungan presentase keyakinan diawali dengan pemecahan sebuah kaidah (rule) yang memiliki gejala majemuk, menjadi kaidah-kaidah (rules) yang memiliki gejala tunggal. Kemudian masing-masing rule baru dihitung CF nya dengan memggunakan persamaan 5. Namun apabila terdapat lebih dari satu gejala, maka CF penyakit dihitung dengan menggunakan persamaan 6. $* 4+$ :

Adapun kelebihan metode Certainty Factor adalah

a. Metode ini cocok dipakai dalam sistem pakar yang mengandung ketidakpastian.

b. Dalam sekali proses perhitungan hanya dapat mengolah 2 data saja, sehingga keakuratan data dapat terjaga.

Sedangkan Kekurangan Metode Certainty Factor adalah *4+ :

a. Pemodelan ketidakpastian yang menggunakan perhitungan metode Certainty Factor biasanya masih diperdebatkan.

b. Untuk data lebih dari 2 buah, harus dilakukan beberapa kali pengolahan data.

c. Nilai CF yang diberikan bersifat subyektif karena penilaian setiap pakar bisa saja berbeda-beda tergantung pengetahuan dan pengalaman pakar.

3. Hasil

a. Data Gejala Kerusakan Fotocopy IR 6000

Gejala kerusakan mesin fotocopy digunakan untuk pertanyaan-pertanyaan yang akan keluar pada saat pengguna melakukan konsultasi. Bedasarkan hasil wawancara penulis dengan pakar, Gejala-gejala umum yang sering muncul pada mesin fotocopy, adalah :
TABEL 2

Data Gejala Kerusakan Mesin Fotocopy

\begin{tabular}{cl}
\hline Kode & \\
Gejala & \multicolumn{1}{c}{ Nama Gejala } \\
\hline G1 & Kertas tidak jalan dari kaset kertas \\
G2 & Kertas ditarik double \\
G3 & Perjalanan continiu/berangkap tidak stabil \\
G4 & Muncul kode Error 100-002 \\
G5 & Hasil blank hitam \\
G6 & Hasil putih polos \\
G7 & Muncul kode Error 061-002 \\
G8 & Kertas berlipat dibawah drum \\
G9 & Muncul kode Error 061-004 \\
G10 & Hasil buram sebagian/hasil buram membentuk garis \\
& lurus \\
G11 & Background bintik-bintik pada permukaan kertas \\
G12 & Kertas tidak lewat dari roll \\
G13 & Muncul kode Error 014-005 \\
G14 & Muncul kode Error 005-001 \\
G15 & Muncul kode Error 020-001 \\
G16 & Hasil copyan bergelombang \\
G17 & Hasil copyan tidak rata/buram pada sebagian hasil \\
& copyan \\
G18 & Muncul kode Error 315-001 \\
G19 & Layar pada monitor tidak tampil \\
G20 & Mesin tidak terdeteksi arus \\
G21 & Hasil copyan bintik-bintik \\
G22 & Hasil bergaris panjang \\
G23 & Hasil copyan buram merata \\
G24 & Hasil copyan tidak melekat pada kertas \\
G25 & Muncul kode Error 350-002 \\
G26 & Kertas tidak lewat dari try ADF \\
G27 & Kertas nyangkut di karet delivery \\
G28 & Swing duplex tidak berfungsi \\
G29 & Muncul kode Jamed paper \\
G30 & Mesin tidak hidup/ mati total \\
G32 & Muncul kode Error 064-002 \\
Muncul beberapa garis pada hasil copyan \\
Gata
\end{tabular}

b. Data Kerusakan Fotocopy IR 6000

Data kerusakan digunakan sebagai hasil dari konsultasi pengguna yang sebelumnya menjawab pertanyaan-pertanyaaan berupa gejala pada saat berkonsultasi. Bedasarkan hasil wawancara penulis dengan pakar, Data kerusakan yang sering terjadi pada mesin fotocopy, adalah :

TABEL 4

DATA KERUSAKAN MESIN FOTOCOPY

\begin{tabular}{cl}
$\begin{array}{c}\text { Kode } \\
\text { Kerusakan }\end{array}$ & \multicolumn{1}{c}{ Nama Kerusakan } \\
K2 & $\begin{array}{l}\text { Karet delivery/Sponge Roll sudah tidak } \\
\text { kasar } \\
\text { Laser bermasalah }\end{array}$ \\
K3 & HVT Unit tidak normal \\
K4 & Corona Wire/ primary carge kotor/putus \\
K5 & Primary transfer/separation kotor/putus
\end{tabular}


Jurnal Penelitian Teknik Informatika Universitas Prima Indonesia (UNPRI) Medan
Volume 1 Nomor 2, Oktober 2018 e-ISSN : 2541-2019
K6

Gear 52/45 kotor/pecah

K7

Cleaning web habis

K8

Developping Unit tidak normal

K9

Motherboard kotor/tidak normal

K10

Permukaan drum bergaris/elemen heater tidak normal

K11

Pemanas (heater roll) longgar atau luka

K12

ADF Unit kotor/tidak normal

Duplex Unit sudah tidak kasar/tidak normal

K14

Power Supplay unit kotor/tidak normal

K15

Cleaning Blade kotor/habis

c. Bobot Nilai Certainty Factor

Bobot nilai Certainty factor diperolah dari tingkat keyakinan pakar pada suatu gejala terhadap jenis kerusakan mesin fotocopy. Bobot nilai ini digunakan untuk proses perhitungan dalam menentukan nilai certainty factor. Berikut tabel bobot nilai Certainty Factor kerusakan mesin fotocopy.

TABEL 5

Bobot Nilal CeRTAINTY FACtoR

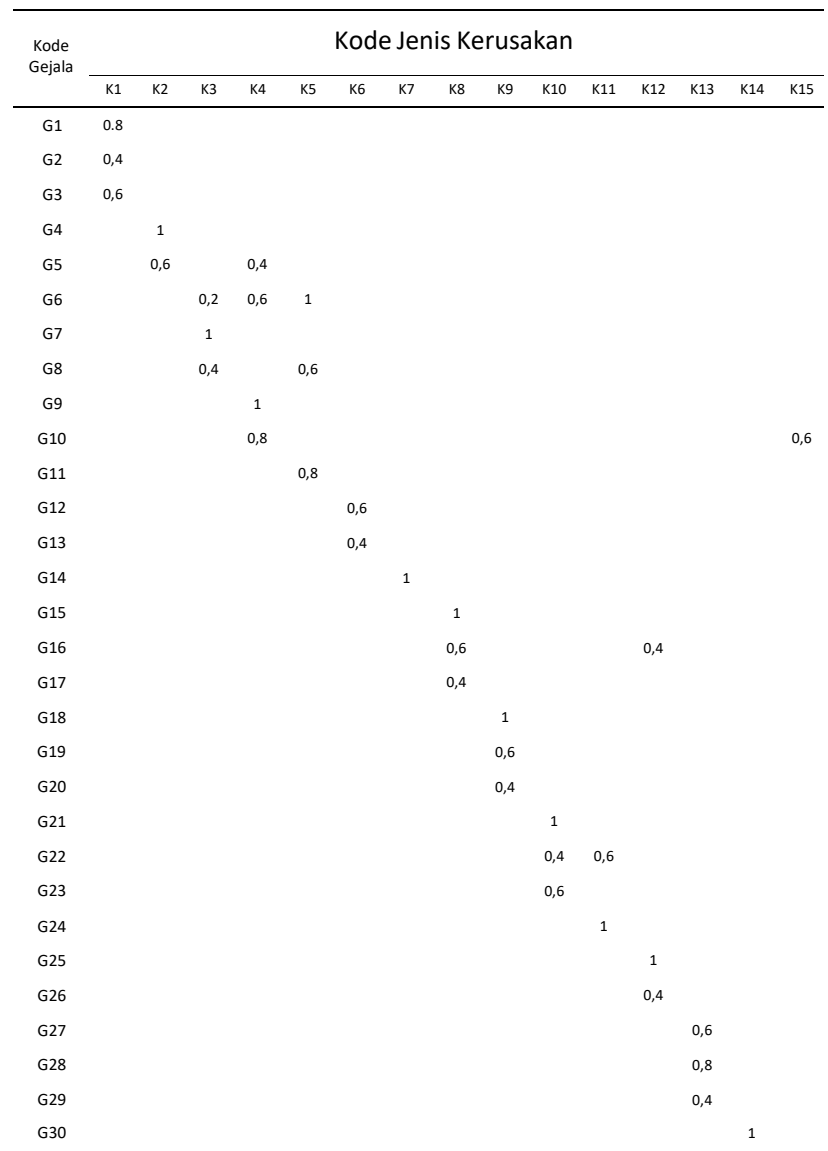

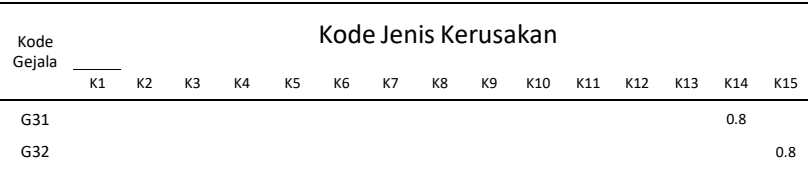

d. Kaidah Aturan/rule

Kaidah aturan ataupun rule digunakan sebagai rule penelusuran kerusakan mesin berdasarkan setiap gejala yang diinput. Berikut tabel kaifah aturan/rule pada sistem pakar mendiagnosa kerusakan mesin fotocopy.

TABEL 6

KAIDAH ATURAN/RULE

Kaidah Aturan/Rule

IF Kertas tidak jalan dari kaset kertas (G1) AND Kertas ditarik

1 double (G2) AND Perjalanan continiu/berangkap tidak stabil (G3) THEN Karet delivery/Sponge Roll sudah tidak kasar (K1)

IF Muncul kode Error 100-002 (G4) AND Hasil blank hitam (G5) THEN Laser bermasalah (K1)

IF Hasil putih polos (G6) AND Muncul kode Error 061-002

3 (G7) AND Kertas berlipat dibawah drum (G8) THEN HVT Unit tidak normal (K3)

IF Hasil blank hitam (G5) AND Hasil putih polos (G6) AND Muncul kode Error 061-004 (G9) AND Hasil buram

4 sebagian/hasil buram membentuk garis lurus (G10) THEN Corona Wire/ primary carge kotor/putus (K4)

IF Hasil putih polos (G6) AND Kertas berlipat dibawah drum

5 (G8) AND Background bintik-bintik pada permukaan kertas (G11) THEN Primary transfer/separation kotor/putus (K5)

- IF Kertas tidak lewat dari roll (G12) AND Muncul kode Error 014-005 (G13) THEN Gear 52/45 kotor/pecah (K06)

IF Muncul kode Error 005-001 (G14) THEN Cleaning web habis (K7)

IF Muncul kode Error 020-001 (G15) AND Hasil copyan

bergelombang (G16) AND Hasil copyan tidak rata/buram pada sebagian hasil copyan (G17) THEN Developping Unit tidak normal (K8)

IF Muncul kode Error 315-001 (G18) AND Layar pada

9 monitor tidak tampil (G19) AND Mesin tidak terdeteksi arus (G20) THEN Motherboard kotor/tidak normal (K09)

IF Hasil copyan bintik-bintik (G21) AND Hasil bergaris panjang (G22) AND Hasil copyan buram merata (G23) THEN

10 Permukaan drum bergaris/elemen heater tidak normal (K10)

IF Hasil bergaris panjang (G22) AND Hasil copyan tidak

11 melekat pada kertas (G24) THEN Pemanas (heater roll) longgar atau luka (K11)

IF hasil Bergelombang (G16) AND Muncul kode Error 350-

12002 (G25) AND Kertas tidak lewat dari try ADF (G26) THEN ADF Unit kotor/tidak normal (K12)

IF Kertas nyangkut di karet delivery (G27) AND Swing duplex

13 tidak berfungsi (G28) AND Muncul kode Jamed paper (G29) THEN Duplex Unit sudah tidak kasar/tidak normal (K13)

IF Mesin tidak hidup/ mati total (G30) AND Muncul kode

14 Error 064-002 (G31) THEN Power Supplay unit kotor/tidak normal (K14)

IF Hasil buram sebagian/hasil buram membentuk garis lurus

15 (G10) Cleaning Blade (G32) and THEN Cleaning Blade kotor/rusak (K15)

d. Penerapan Metode Certainty Factor 
Seorang costumer/user datang berkonsultasi dengan sistem pakar untuk mengetahui permasalah/kerusakan mesin fotocopynya. Sistem pakar mempunyai basis pengetahuan sebagai berikut:

If Kertas tidak jalan dari kaset kertas

And Kertas ditarik double

And Perjalanan continiu/berangkap tidak stabil

Then Karet delivery/Sponge Roll sudah tidak kasar

Langkah pertama yang harus dilakukan adalah, pakar memberikan nilai CF untuk masing-masing gejala.

CF(pakar) Kertas tidak jalan dari kaset kertas $=0.8$

$\mathrm{CF}$ (pakar) Kertas ditarik double $=0.4$

$\mathrm{CF}$ (pakar) Perjalanan continiu/berangkap tidak stabil

$=0.6$

Misalkan user memilih jawaban saat konsultasi

sebagai berikut:

Kertas tidak jalan dari kaset kertas $=1$

Hasil Kertas ditarik double $=1$

Perjalanan continiu/berangkap tidak stabil $=1$

Kaidah-kaidah atau rule awal yang memiliki 3 premis

(gejala), dipecah menjadi beberapa premis tunggal sebagai berikut:

Kaidah 1.1

If Kertas tidak jalan dari kaset kertas

Then Karet delivery/Sponge Roll sudah tidak kasar

Kaidah 1.2

If Hasil Kertas ditarik double

Then Karet delivery/Sponge Roll sudah tidak kasar

Kaidah 1.3

If Perjalanan continiu/berangkap tidak stabil

Then Karet delivery/Sponge Roll sudah tidak kasar

Kaidah-kaidah atau rule yang baru tersebut

kemudian dihitung nilai CF nya dengan mengalikan

CF(pakar) dengan CF(user) menjadi:

Kaidah $1.1=0.8 * 1=0.8$

Kaidah $1.2=0.4 * 1=0.4$

Kaidah $1.3=0.6 * 1=0.6$

Kombinasikan CF1.1 dengan CF1.2 dengan rumus

sebagai berikut:

CFcombine (CF1,CF2) = CF1 + CF2 * (1-CF1), sehingga

menjadi berikut:

Maka :

CFcombine (CF1,CF2)

$=0.8+0.4 *(1-0.8)$

$=0.8+0.4 *(0.2)$

$=0.8+0.08$

$=0.88$ (CFold)

CFcombine (CFold1,CF1.3)

$=0.88+0.6 *(1-0.88)$

$=0.88+0.6 *(0.12)$

$=0.88+0.072$

$=0.952$ (CFcombine)

Persentase keyakinan $=$ Cfcombine $* 100$

$=0.952 * 100$

\section{$=95.2 \%$}

Dengan demikian dapat disimpulkan bahwa perhitungan Certainty Factor kerusakan Karet delivery/Sponge Roll pada mesin fotocopy milik user tersebut memiliki persentase tingkat keyakinan $95.2 \%$.

e. Implementasi Sistem

Secara garis besar, tampilan antamuka perancangan sistem pakar untuk mendiagnosa kerusakan mesin fotocopy canon IR 6000 menggunakan metode certainty factor, adalah sebagai berikut :

1. Tampilan Form Konsultasi

Tahapan konsultasi merupakan tahapan berkonsultasi. Dimana sistem akan memberikan pertanyaan seputar gejala kerusakan mesin fotocopy Canon IR 6000 dan user diminta memilih jawaban "YA" ataupun "TIDAK".

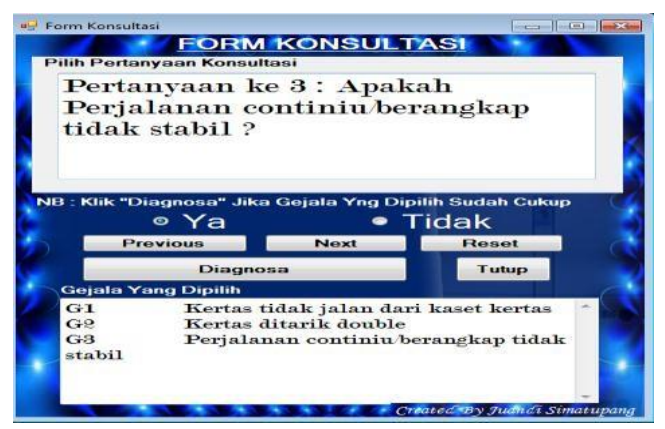

Gambar 1. Tampilan Form Konsultasi

Pada gambar 1, user melakukan konsultasi dengan memilih jawaban "YA" pada 3 pertanyaan yang ditampilkan sistem, yaitu:

G1 : Kertas Tidak Jalan Dari Kaset Kertas

G2: Kertas ditarik double

G3 : Perjalan continiu berangkap tidak stabil

Setelah merasa cukup, user diminta untuk memilih tombol diagnosa.

2. Tampilan Form Hasil Konsultasi

Hasil diagnosa dari jawaban user sebelumnya akan ditampilkan dalam form hasil diagnosa berikut ini :

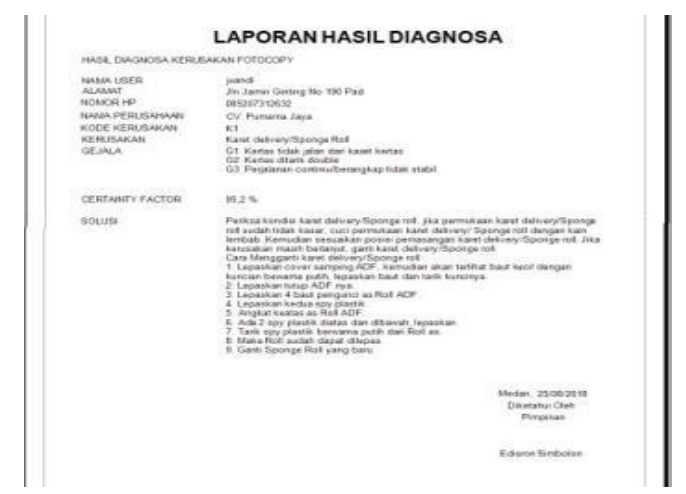

Gambar 2. Tampilan Form Hasil Konsultasi Berdasarkan jawaban user sebelumnya yaitu G1, G2 
dan G3, maka sistem memberikan hasil berupa kode kerusakan yaitu K1 dengan nama kerusakan "Karet Delivery/Sponge Roll sudah tidak kasar, dengan nilai certainty factor $95.2 \%$. Selain itu sistem juga menampilkan gambar kerusakan dan solusi untuk jenis kerusakan.

\section{Kesimpulan}

Berdasarkan penelitian yang telah dilakukan selama membuat aplikasi sistem pakar diagnosa kerusakan mesin fotocopy Canon IR 6000 dengan metode Certainty Factor ini, maka dapat ditarik beberapa kesimpulan sebagai berikut:

1. Sistem pakar ini menggunakan metode Certainty Factor, dimana metode mengumpulkan pertanyaanpertanyaan serta solusi dari sistem tersebut dijawab dengan mengacu pada aturan/rule yang dipakai, dan data-data yang didapat selama penelitian.

2. Aplikasi sistem pakar ini digunakan untuk mempercepat penanganan terhadap kerusakan mesin fotocopy oleh operator/pengguna mesin fotocopy yang sering terjadi ketika proses mengcopy sedang berlangsung.

3. Aplikasi sistem pakar ini diharapkan mampu menggantikan sementara peran tenaga ahli/teknisi yang kedatangannya memerlukan waktu yang lama untuk melakukan perbaikan kerusakan mesin fotocopy.

4. Hasil diagnosa dan solusi yang ditampilkan dalam sistem pakar sudah cukup lengkap dan akurat sehingga pengguna yang sudah sering menggunakan mesin fotocopy seharusnya dapat melakukan perbaikan kerusakan mesin fotocopy berdasarkan solusi yang ditampilkan.

5. Aplikasi ini memiliki tampilan-tampilan yang user friendly sehingga pemakai dapat menggunakan aplikasi ini dengan mudah.

6. Hasil diagnosa dalam sistem pakar ini dapat dicetak menjadi laporan/report, sebagai bukti bahwa diagnosa benar telah dilakukan.
7. Diharapkan aplikasi sistem pakar ini dikembangkan menjadi aplikasi multiuser dengan basis mobile sehingga fungsi dan kegunaannya dapat dipakai secara luas oleh banyak orang dimanapun dan kapanpun sesuai dengan Operating System pada mobile tersebut, selain itu diharapkan adanya penelitian terhadap tipe mesin fotocopy Canon lainnya yang lebih update dari Canon IR 6000.

\section{REFERENSI}

[1] Akim, M. H. P, \& Budi, S. G., “Perancangan Sistem Pakar Deteksi Kerusakan Printer Canon berbasis web", Jurnal KAPUTAMA, Vol.7 No.1, Juli 2013: 3643.

[2] Andri, S., \& Hengki, A. T., "Sistem Pakar Kerusakan Mesin Jahit dengan Metode

Certainty Factor Berbasis Android", Journal of Applied Intelligent System, Vol.1, No. 1, Februari 2016: 36-47.

[3] Solichin A., "MySQL 5 Dari Pemula Hingga Mahir", Buku Komputer Gratis Dari Achmatim.Net, 2010

[4] Mulyanto A. R., "Rekayasa Perangkat Lunak Jilid 3", Direktorat Pembinaan Sekolah Menengah Kejuruan, Jakarta, 2008.

[5] Canon Inc, July 2000 “ IR 5000/IR6000 SERVICE MANUAL REVISION 0" Printed in Japan.

[6] Prasetyo E., 2016, Jurnal TIPS, "Rancang Bangun Aplikasi Persediaan Bahan Praktikum Pada SMK Negeri 3 Model Sekayu" Volume V, No 2, Hal.1-11.

[7] M. Arhami, 2010 "Konsep Dasar Sistem Pakar", Andi Publisher, Yogyakarta.

[8] Rosa A.S. \& M. Shalahuddin.2018. "Rekayasa Perangkat Lunak". Bandung: Informatika Bandung.

[9] Yesputra, R, "Belajar Visual Basic .NET dengan Visual Studio 2010", Royal Asahan Press, Kisaran, 2017

[10] T. Sutojo., Edy Mulyanto, S.Si.,M.Kom., Dr. VinventSuhartono, "KecerdasanBuatan", Andi Yogyakarta, Semarang, 2010. 